\title{
What is the quality of clinical practice guidelines for the treatment of acute lateral ankle ligament sprains in adults? A systematic review
}

\author{
Toni Green ${ }^{1,2^{*}}$, Grant Willson², Donna Martin ${ }^{3}$ and Kieran Fallon ${ }^{1}$
}

\begin{abstract}
Background: Acute lateral ankle ligament sprains (LALS) are a common injury seen by many different clinicians. Knowledge translation advocates that clinicians use Clinical Practice Guidelines (CPGs) to aid clinical decision making and apply evidence-based treatment. The quality and consistency of recommendations from these CPGs are currently unknown. The aims of this systematic review are to find and critically appraise CPGs for the acute treatment of LALS in adults.

Methods: Several medical databases were searched. Two authors independently applied inclusion and exclusion criteria. The content of each CPG was critically appraised independently, by three authors, using the Appraisal of Guidelines for REsearch and Evaluation (AGREE II) instrument online version called My AGREE PLUS. Data related to recommendations for the treatment of acute LALS were abstracted independently by two reviewers.

Results: This study found CPGs for physicians and physical therapists (Netherlands), physical therapists, athletic trainers, physicians, and nurses (USA) and nurses (Canada and Australia). Seven CPGs underwent a full AGREE II critical appraisal. None of the CPGs scored highly in all domains. The lowest domain score was for domain 5, applicability (discussion of facilitators and barriers to application, provides advice for practical use, consideration of resource implications, and monitoring/ auditing criteria) achieving an exceptionally low joint total score of 9\% for all CPGs. The five most recent CPGs scored a zero for applicability. Other areas of weakness were in rigour of development and editorial independence.

Conclusions: The overall quality of the existing LALS CPGs is poor and majority are out of date. The interpretation of the evidence between the CPG development groups is clearly not consistent. Lack of consistent methodology of CPGs is a barrier to implementation.
\end{abstract}

Systematic review: Systematic review registered with PROSPERO (CRD42015025478).

Keywords: Physiotherapy, Physical Therapy/Rehabilitation, Physical Therapy, Modalities, Non-Steroidal Anti-Inflammatory Drugs (NSAIDs)

\footnotetext{
* Correspondence: Toni.Green@canberra.edu.au

${ }^{1}$ ANU Medical School, College of Health and Medicine, Australian National

University, ACT, Acton, Australia

2Discipline of Physiotherapy, University of Canberra, ACT, Bruce 2617,

Australia

Full list of author information is available at the end of the article
}

(c) The Author(s). 2019 Open Access This article is distributed under the terms of the Creative Commons Attribution 4.0 International License (http://creativecommons.org/licenses/by/4.0/), which permits unrestricted use, distribution, and reproduction in any medium, provided you give appropriate credit to the original author(s) and the source, provide a link to the Creative Commons license, and indicate if changes were made. The Creative Commons Public Domain Dedication waiver (http://creativecommons.org/publicdomain/zero/1.0/) applies to the data made available in this article, unless otherwise stated. 


\section{Background}

Lateral ankle ligament sprains (LALS) are common $[1,2]$ and costly [3] soft tissue injuries. An acute LALS is defined as "an acute traumatic injury to the lateral ligament complex of the ankle joint as a result of excessive inversion of the rear foot or a combined plantarflexion and adduction stress to the foot. This injury usually results in initial deficits of function and disability" [4]. This definition of an acute LALS has been endorsed by the International Ankle Consortium [5-7]. The acute phase is usually defined as less than two weeks after the injury [8]. This acute phase corresponds to the first phase of biological ligament healing known as the inflammatory phase [9].

LALS are a common occurrence in the general population, indoor sports [10], field athletes [11], military personnel [12] and dancers [13, 14]. Acute phase signs and symptoms are often weakness, stiffness, pain and swelling. Generally these resolve within six weeks but may persist for years [15]. A history of LALS may predispose to reduced movement such as ankle dorsiflexion [16]. Complications from LALS are also costly and include chronic ankle instability (CAI) [16, 17], post traumatic ankle osteoarthritis (PTOA) [18] and an increased fall risk in older populations [19]. CAI is defined as "an encompassing term used to classify a subject with both mechanical and functional instability of the ankle joint. To be classified as having chronic ankle instability, residual symptoms ("giving way" and feelings of ankle joint instability) should be present for a minimum of one year post-initial sprain" [4]. It is usual for a CAI to be under the care of a medical practitioner and/or physical therapist over an extended time, sometimes years.

An acute LALS may be seen by many different people some of whom are not experienced highly trained clinicians. This is suboptimal as the condition requires correct diagnosis and if necessary, a referral. Acute LALS injuries may present to first aid officers at the workplace or at sporting events, to emergency departments [20,21] or to a variety of primary contact clinicians. Sports physicians, physical therapists, athletic trainers, nurse practitioners, school nurses, doctors in general practice, accident and emergency staff (doctors, nurses and physical therapist), community pharmacists (pharmacists, pharmacy assistants and shop assistants) and first aid officers [22] may diagnose, advise, refer or offer treatments for acute LALS based on their prior education, training, continuing professional development and CPGs.

Knowledge translation has been described by Lang as "any activity or process that facilitates the transfer of high quality evidence from research into effective changes in health policy, clinical practice or products" [23]. It involves research, education, quality improvement and electronic systems [23]. CPGs are used to encourage knowledge translation of evidence based medicine [24] to the clinical setting. The development of CPGs is constantly improving and assistance in developing CPGs can be found by reference to such instruments as the Appraisal of Guidelines for REsearch \& Evaluation II (AGREE II) [25] .

\section{Objectives}

The primary aim of this systematic review is to find and critically appraise all CPGs related to the treatment of acute LALS in adults. The secondary aim is to determine if CPGs are using the same studies to support their treatment recommendations for acute LALS.

\section{Methods}

\section{Protocol and registration}

The search strategy, inclusion and exclusion criteria were specified and documented in advance and registered with PROSPERO (registration number: CRD42015025478).

\section{Database search strategy}

An electronic search was conducted across medical literature databases. All searches were performed in October 2017. The Cochrane Library, MEDLINE, CINAHL, Sportdiscus, Web of Science, Scopus, USA National Guideline Clearinghouse and PEDro databases were searched to find all CPGs for treatment of LALS. The search strategy was agreed upon after discussion with an experienced librarian and was refined through team discussion. The search strategy of medical databases used medical subject headings and free text search terms (mesh). Specifically, terms of ("ankle injur" OR "ankle sprain"” OR "sprained ankle*") and guideline* were used. In addition, other sources such as Google Scholar, handsearching and personal communication supplied guidelines. Only CPGs published in English were retrieved. See Additional file 1: Search Strategy and List of Articles, excel spreadsheet for more details.

\section{Study selection}

Records were imported into referencing software (Endnote X7, Thomson Reuters, New York, New York USA) and all duplicates were removed using this software.

\section{Inclusion criteria}

The review considered CPGs for adults 18 years and older with LALS and acute treatment recommendations.

\section{Exclusion criteria}

The review did not consider CPGs for adults 18 years and older with diagnoses of ankle fractures or syndesmosis ankle sprains. The authors are aware that distal fibular avulsion fractures are common in LALS and are managed as LALS. 


\section{Data collection and risk of Bias}

Study inclusion was determined by 2 authors (TG, GW) who independently considered title, abstract and full text. There was an absolute rate of agreement between the two reviewers of $94 \%$ and a prevalence-adjusted and bias-adjusted kappa [26] of 0.88 (95\% CI 0.68 to 0.98). Disagreement was resolved during discussion with another author (KF).

\section{AGREE II data collection process}

The Appraisal of Guideline Research and Evaluation II (AGREE II) [25] is a standardised and internationally recognised CPG critical appraisal tool. It was developed to address the variable quality of CPGs by supplying a structured process to evaluate the methodological rigour and transparency of CPG development and quality of reporting of CPG development. The AGREE II consists of 23 items, which are grouped into six domains: scope and purpose (3 items), stakeholder involvement (3 items), rigour of development (8 items), clarity of presentation (3 items), applicability (4 items), and editorial independence ( 2 items). Each of these items is rated on a seven-point scale, ranging from $1=$ strongly disagree to $7=$ strongly agree. In addition, the two final items provide the appraiser with the opportunity to make an overall judgement of the CPG. The appraisers rate the overall quality of the guideline on a seven-point scale ranging from 1 = lowest possible quality to $7=$ highest possible quality. The appraiser can also respond to the question "I would recommend this guideline for use" by selecting the most appropriate response choice from "yes," "yes with modifications" or "no." Domain scores are calculated by calculating the sum of all the scores of the individual items in a domain and then by scaling the total as a percentage of the maximum possible score for that domain. The My AGREE PLUS is the online software version of the tool and appraisers are sent hyperlinks to the group appraisal site via email. The appraisers appraise the guideline online using this software. The My AGREE PLUS calculates a score out of 100 for each domain for each guideline.

The AGREE II [25] has undergone both validity [27] and reliability testing [28] and results have been published in peer-reviewed journals. These results have shown the AGREE II to be a valid and reliable instrument, with sufficient inter-rater reliability. The AGREE II tool is supported by two systematic reviews that found that it is the only validated tool for assessment of CPG and, in addition, it enables production of a numerical score for the critically appraised CPG $[29,30]$. AGREE II recommends that at least two and preferably four appraisers rate a single practice guideline to increase the reliability of the assessment.

Three authors (TG, DM, KF) read the AGREE II user manual and watched the online tutorials from the AGREE
II website (http://www.agreetrust.org/agree-ii/). All CPGs were reviewed independently, and conflicts were resolved by discussion until consensus was reached between all 3 authors. This was consistent with the methodology of a systematic review of osteoarthritis guidelines [31] and a systematic review of low back pain guidelines [32].

\section{Recommendations for treatment of acute LALS data collection process}

A data abstraction form in Microsoft Excel (2016)) was developed, piloted, and changed, as necessary. Data was later abstracted by one reviewer (TG) and verified independently by another reviewer (GW). Recommendations for the treatment of acute LALS were abstracted. Recommendations from CPGs about the use of specific treatment options were dichotomized to "recommended" or "not recommended". In addition, a descriptive synthesis of the recommendations and their supporting evidence was undertaken. It was assessed if the same evidence had been used during formulation of the CPGs.

\section{Results \\ Study selection}

Forty-three articles were exported to Endnote X7 [33]. Twenty duplicates were removed. Twenty-three articles were independently reviewed. Initially nine CPGs were considered suitable. Subsequently, two CPGs were considered not suitable after discussion and agreement by authors (TG, GW, KF), namely a CPG for return to play after an LALS [34] and a syndesmosis injury CPG [35]. Seven CPGs were suitable for review using AGREE II see Fig. 1: Results of the search strategy for international guidelines that have recommendations for acute management of LALS and Table 1 for details of the included CPGs.

Two CPGs were written for nurses [38, 39], one CPG for American athletic trainers [41], two CPGs for Dutch physical therapists and physicians [37, 40], one CPG for American physical therapists [42], and one organisational CPG for physicians and nurses [36]. The Canadian nurse CPG was web based [39].

\section{AGREE II analysis}

The AGREE II scores, which were derived from the three independent reviewers' scores as a percentage of the maximum possible score, are shown in Fig. 2. The highest domain scores were for domain 4: clarity of presentation with all CPGs scoring above $61 \%$. The second highest domain scores were for domain 1: scope and purpose with five CPGs scoring above 67\%. The 2012 Dutch CPG [40] was the only CPG to receive $100 \%$ score in any domain (domain 4).

The lowest overall domain score was for domain 5: applicability (discussion of facilitators and barriers to 


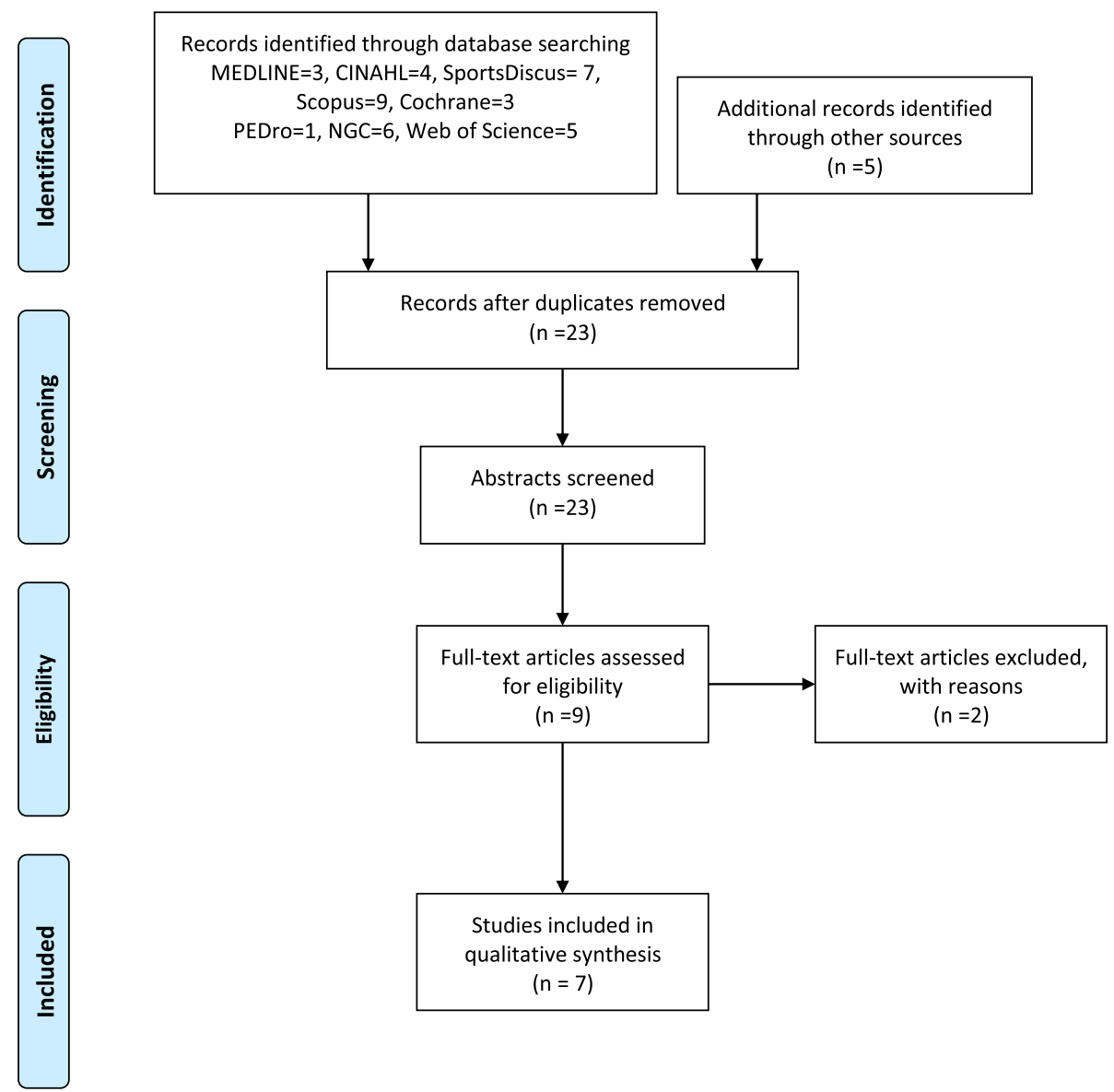

Fig. 1 Results of the search strategy for international guidelines that have recommendations for acute management of lateral ankle ligament sprains. SR CPGS LALS PRISMA Flow Diagram

application, provides advice for practical use, consideration of resource implications, and monitoring/auditing criteria) scoring a joint total score of $9 \%$ for all CPGs. The five most recent CPGs scored a zero for applicability. The second lowest domain score was domain 6: editorial independence. Three CPGs scored zero for this domain $[37,41,42]$.

\section{Descriptive synthesis of studies for recommendations}

For each of the appraised CPGs, the Level of Evidence (LOE) and Strength of Recommendation (SOR) grading scales used in the formulation of the respective recommendations were extracted from the guideline and tabulated (Table 2 Methods used to assess the quality of evidence to support the recommendations). Two CPGs $[38,39]$ had not reported the scale/category/LOE/SOR for their recommendations for treatment of LALS.

This study's secondary aim was to determine if CPGs were using the same research studies to support their recommendations for treatments in the acute LALS phase. To that end the acute treatments and the supporting research cited for the specific recommended acute treatment in the CPGs were tabulated and organised according to the CPG's age, with 1 showing the oldest CPG and 7 being the most recent (Table 3). Any sections that were blank in Table 3 shows that this acute treatment choice was not included in the CPG. All guidelines recommended progressive weightbearing with support. Ice was also recommended by all guidelines. Heat was not recommended by three CPGs. Ultrasound was not recommended by four guidelines [37, 40-42]. Conflicting recommendations occurred in four recommendations: graded joint mobilisations or mobilisation with movement, pulsating short wave diathermy, electrotherapy, and low-level laser. Thirty-one recommendations of the seventy-two were made without any studies cited to support this decision. These recommendations were decided upon by expert opinion or consensus.

The studies that were cited in three or more of the CPGs were noted (Table 4). Five of these common studies were systematic reviews. The most cited systematic reviews were cited by four guidelines. 
Table 1 Description of the lateral ankle ligament sprain clinical practice guidelines

\begin{tabular}{|c|c|c|c|c|}
\hline Number & Publication & Name & Author & Target Health Professional \\
\hline 1 & 2006 & Health care guideline: ankle sprain. & $\begin{array}{l}\text { Fongemie, } \\
\text { A., et al. } \\
{[36]}\end{array}$ & $\begin{array}{l}\text { Physicians and nurses from Institute for Clinical } \\
\text { Systems Improvement. www. ICSI. Org Zugriff am }\end{array}$ \\
\hline 2 & 2006 & $\begin{array}{l}\text { KNGF guideline for physical therapy in patients with } \\
\text { acute ankle sprain-practice guidelines. }\end{array}$ & $\begin{array}{l}\text { Wees, P., } \\
\text { et al. [37] }\end{array}$ & $\begin{array}{l}\text { Physical therapists who are members of the Royal } \\
\text { Dutch Society of Physical Therapy }\end{array}$ \\
\hline 3 & 2009 & $\begin{array}{l}\text { Occupational Health Nurse Practitioner (OHNP) Clinical } \\
\text { Practice Guideline (CPG), Ankle/Foot Injury. }\end{array}$ & $\begin{array}{l}\text { Fonceca } \\
{[38]}\end{array}$ & $\begin{array}{l}\text { Occupational health nurse practitioner from Carepoint } \\
\text { Industrial Health Services }\end{array}$ \\
\hline 4 & 2011 & Adult Care, Chapter 7, Musculoskeletal System. & $\begin{array}{l}\text { Health } \\
\text { Canada } \\
{[39]}\end{array}$ & $\begin{array}{l}\text { Nurses employed by Health Canada First Nations and } \\
\text { Inuit Health Branch (FNIHB) CPG for Nurses in Primary } \\
\text { Care }\end{array}$ \\
\hline 5 & 2012 & $\begin{array}{l}\text { Diagnosis, treatment, and prevention of ankle sprains: an } \\
\text { evidence-based clinical guideline. }\end{array}$ & $\begin{array}{l}\text { Kerkhoffs, } \\
\text { G. M., et al. } \\
{[40]}\end{array}$ & $\begin{array}{l}\text { Physical therapists, orthopaedic and trauma surgeons, } \\
\text { family, rehabilitation, occupational, and sports } \\
\text { physicians, radiologists, and professionals involved in } \\
\text { sport massage }\end{array}$ \\
\hline 6 & 2013 & $\begin{array}{l}\text { National Athletic Trainers' Association position statement: } \\
\text { conservative management and prevention of ankle } \\
\text { sprains in athletes. }\end{array}$ & $\begin{array}{l}\text { Kaminski, } \\
\text { T. W., et al. } \\
{[41]}\end{array}$ & $\begin{array}{l}\text { Athletic trainers who are members of the American } \\
\text { Athletic Trainers' Association }\end{array}$ \\
\hline 7 & 2013 & $\begin{array}{l}\text { Ankle stability and movement coordination impairments: } \\
\text { ankle ligament sprains: CPG linked to the international } \\
\text { classification of functioning, disability and health from } \\
\text { the orthopaedic section of the American Physical } \\
\text { Therapy Association. }\end{array}$ & $\begin{array}{l}\text { Martin, R. } \\
\text { L., et al. } \\
{[42]}\end{array}$ & $\begin{array}{l}\text { Physical therapists who are members of the American } \\
\text { Physical Therapy Association }\end{array}$ \\
\hline
\end{tabular}

\section{Discussion}

The primary aim of this systematic review is to identify and critically appraise evidence based CPGs for the acute treatment of LALS in adults. Two CPGs were written for nurses [38, 39], one CPG for American athletic trainers [41], two Dutch CPGs [37, 40], one CPG for American physical therapists [42], and one organisational CPG for physicians and nurses [36]. The more recent Dutch CPG is a multidisciplinary guideline who targets all care providers of LALS [40]. Considering that these are such common $[1,2]$ and potentially costly [3] soft tissue injuries it is surprising that so few CPGs exist for LALS.

It is also surprising that no published CPGs exist for community pharmacies (pharmacists, pharmacy assistants and shop assistants) or first aid officers. It is common for acute LALS patients to seek free advice at pharmacies. First aid officers also offer free advice and early care to thousands of acute LALS patients at work, sporting, and public events. In a New Zealand study [106], $96 \%$ of pharmacists recommended RICE (rest, ice, compression, elevation) and saw a mean of nine acute LALS per month. In Australia, pharmacists use a handbook [107] as a resource to guide decision making for acute LALS. The handbook advices RICE, early mobilisation, analgesics, and topical non-steroidal anti-inflammatory drugs (NSAIDs). Possibly, these pharmacists use other forms of knowledge translation such as educational meetings instead of CPGs [108]. It should be noted that four guidelines [36, 38-40] recommended NSAIDs as advised by the pharmacists.
This study is the first systematic review to evaluate the quality of LALS CPGs using the AGREE II tool. The AGREE II consists of 23 items, which are grouped into six domains: scope and purpose (3 items), stakeholder involvement (3 items), rigour of development (8 items), clarity of presentation (3 items), applicability (4 items), and editorial independence ( 2 items). None of the CPGs scored highly in all domains. The highest domain scores were for domain 4, clarity of presentation with all CPGs scoring above $61 \%$. The second highest domain score was domain 1, scope and purpose with 5 CPGs scoring above $67 \%$. The 2012 Dutch CPG [40] was the only CPG to receive an $100 \%$ score in any one domain (domain 4).

The lowest domain score was for domain 5, applicability (discussion of facilitators and barriers to application, provides advice for practical use, consideration of resource implications, and monitoring/auditing criteria) achieving an exceptionally low joint total score of $9 \%$ for all CPGs. The five most recent CPGs scored zero for applicability. This is a disturbing finding and further research is needed as to why these CPGs did not address these key components of knowledge translation for clinicians. However, it is probably due to the guidelines being published in peer reviewed journals, the authors being limited by the space available for description of the guideline development process. Conversely, peer review may explain any high scores in editorial independence [40].

Failure to assess whether CPGs are being used correctly is also of concern. Fortunately, this has been assessed independent of the guideline developers. Several papers 
600

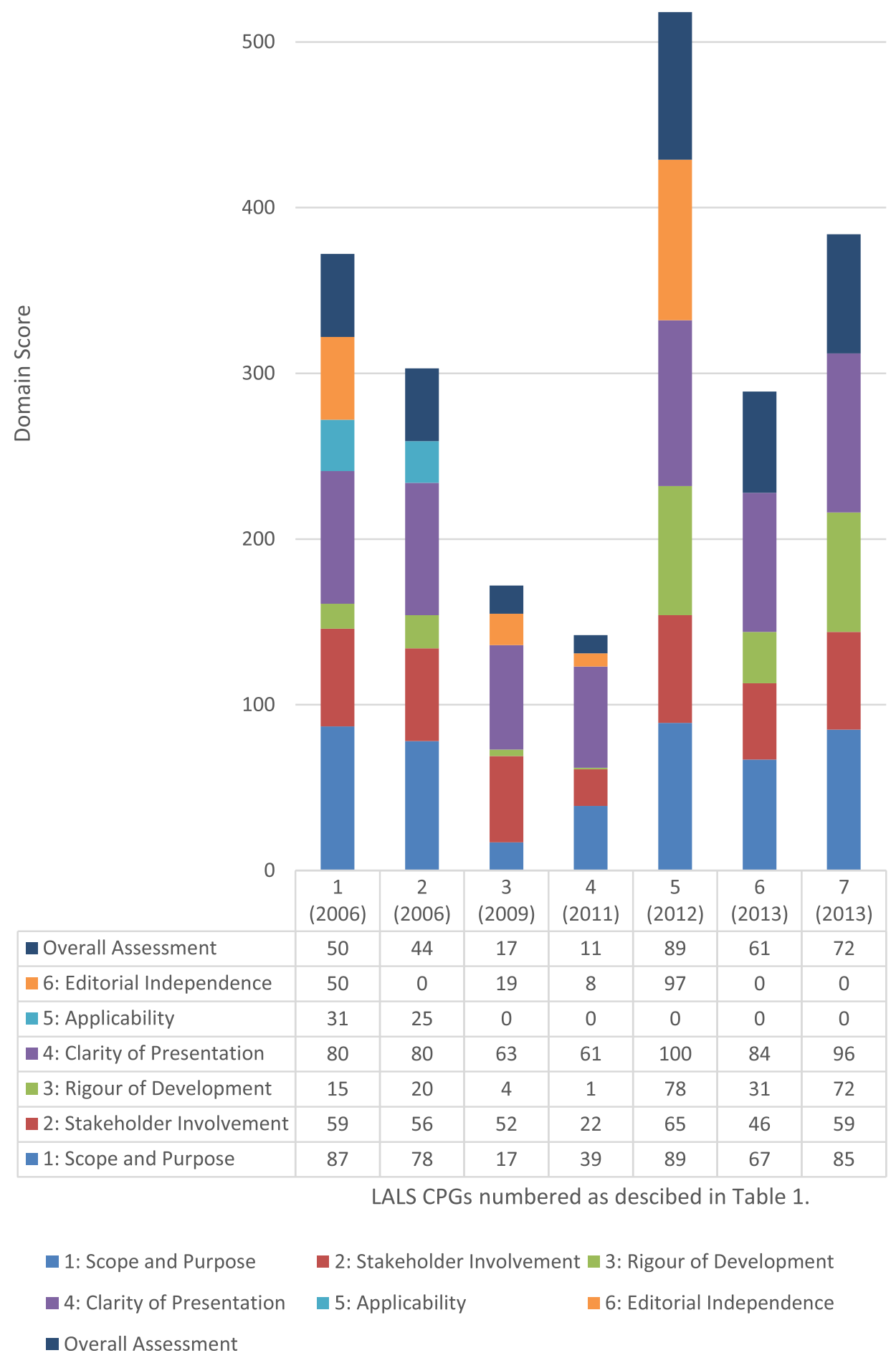

Fig. 2 AGREE I| results of lateral ankle ligament sprains clinical practice guidelines. AGREE I| results of LALS CPGs 
Table 2 Methods used to assess the quality of evidence to support the recommendations

Guideline 1, 2006 Evidence Grading System

A. Primary Reports of New Data Collection:

Class A: Randomized, controlled trial

Class B: Cohort study

Class C: Non-randomized trial with concurrent or historical controls, Case-control study, Study of sensitivity and specificity of a diagnostic test, Population-based descriptive study

Class D: Cross-sectional study, Case series, Case report

B. Reports that Synthesize or Reflect upon Collections of Primary Reports:

Class M: Meta-analysis, Systematic review, Decision analysis, Costeffectiveness analysis

Class R: Consensus statement, Consensus report, Narrative review

Class X: Medical opinion

\section{Guideline 2, 2006 LEVELS OF EVIDENCE}

1 one systematic review (A1 quality; see below) or at least two independent studies of A2 quality;

2 at least two independent studies of B quality

3 one study of $A 2$ or B quality, or several studies of $C$ quality;

4 expert opinion, e.g. that of members of the Guideline Committee

Quality levels (intervention and prevention)

A1 Systematic reviews including at least some studies of A2 quality, with results consistent across individual studies.

A2 Randomized comparative clinical trial (RCT) of sound methodological quality (randomized double-blind controlled trial) of sufficient size and consistency.

B Randomized comparative clinical trial $(\mathrm{RCT})$ of moderate quality or insufficient size; other comparative study (non-randomized comparative cohort study or case-control study).

C Non-comparative study.

D Expert opinion, e.g. that of members of the Guideline Committee.

Guideline 3, 2009 none said

Guideline 4, 2011 none said

Guideline 5, 2012 Classification of methodological quality of individual studies

A1 Systematic review of at least two independently conducted studies of A2 level

A2 Randomised double-blind comparative clinical research of good quality of sufficient size Research relative to a reference test (a 'golden standard') with predefined cut-off points and independent assessment of the results of a test and golden standard, on a sufficiently large series of consecutive patients who all have had the index and reference test Prospective cohort study of sufficient size and follow-up, at which adequately controlled for 'confounding' and selective follow-up sufficient is excluded.

B Comparative research, but not with all the features as mentioned under A2 (this includes patient-control research, cohort study) Research relative to a reference test, but not with all the attributes that are listed under A2 Prospective cohort study, but not with all the features as mentioned under $\mathrm{A} 2$ or retrospective cohort study or patientmonitoring research

C Not comparative research

D Opinion of experts
Table 2 Methods used to assess the quality of evidence to support the recommendations (Continued)

Conclusions based on

1 Research of level A1 or at least two examinations of level A2 performed independently of each other, with consistent results

2 One examination of level A2 or at least two examinations of level B, performed independently of each other

3 One examination of level B or C

4 Opinion of experts

Guideline 6, 2013

The taxonomy includes ratings of $\mathrm{A}, \mathrm{B}$, or $\mathrm{C}$ for the strength of recommendation for a body of evidence. A being consistent and good quality patient-oriented evidence. $\mathrm{B}$ being inconsistent and limited quality patient-oriented evidence. C based on consensus, usual practice, opinion, disease-oriented or case series for studies of diagnosis, treatment, prevention, or screening. They recommendations were graded

according to the Strength of Recommendation Taxonomy

Guideline 7, 2013 LEVELS OF EVIDENCE

I Evidence obtained from high-quality diagnostic studies, prospective studies, or randomized controlled trials

Il Evidence obtained from lesser-quality diagnostic studies, prospective studies, or randomized controlled trials (e.g., weaker diagnostic criteria and reference standards, improper, randomization, no blinding, less than $80 \%$ follow-up)

III Case-control studies or retrospective studies

IV Case series

$\checkmark$ Expert opinion

\section{GRADES OF RECOMMENDATION BASED ON STRENGTH OF EVIDENCE}

A Strong evidence A preponderance of level I and/or level II studies support the recommendation. This must include at least 1 level I study

B Moderate evidence. A single high-quality randomized controlled trial or a preponderance of level II studies support the recommendation

C Weak evidence A single level II study or a preponderance of level III and IV studies,s including statements of consensus by content experts, support the recommendation

D Conflicting evidence Higher-quality studies conducted on this topic disagree with respect to their conclusions. The recommendation is based on these conflicting studies

E Theoretical/ foundational evidence A preponderance of evidence from animal or cadaver studies, from conceptual models/principles, or from basic science/bench research supports this conclusion

F Expert opinion Best practice based on the clinical experience of the guideline's development team

published by Dutch research groups investigating compliance with an LALS CPG have found moderate compliance by physical therapists in the Netherlands $[109,110]$. Recently another Dutch observational study using multi-level analyses of data found discrepancy between the CPGs and practice of the physical therapists [111]. They found that, although not recommended in the CPGs, manual manipulation was applied during treatment in $21 \%$ of the patients with functional instability and that patients with acute LALS had only a $38 \%$ chance of being treated according to the CPG. 
Table 3 Supporting evidence in each of the seven clinical practice guidelines for acute treatment of lateral ankle ligament sprains

\begin{tabular}{|c|c|c|c|c|c|c|c|}
\hline Acute Treatment & $\begin{array}{l}1[36] \\
(2006)\end{array}$ & $\begin{array}{l}2[37] \\
(2006)\end{array}$ & $\begin{array}{l}3[38] \\
(2009)\end{array}$ & $\begin{array}{l}4[39] \\
(2011)\end{array}$ & $\begin{array}{l}5[40] \\
(2012)\end{array}$ & $\begin{array}{l}6[41] \\
(2013)\end{array}$ & $\begin{array}{l}7[42] \\
(2013)\end{array}$ \\
\hline $\begin{array}{l}\text { Progressive weight bearing with support depending on severity } \\
\text { (tape, brace, boot, casting) }\end{array}$ & $\begin{array}{l}R[43- \\
45]\end{array}$ & $\begin{array}{l}\text { R [45, } \\
46]\end{array}$ & $\mathrm{R}$ & R & $\mathrm{R}[45-48]$ & $\begin{array}{l}R[45,47, \\
49]\end{array}$ & $\begin{array}{l}R[47,48 \\
50-56]\end{array}$ \\
\hline Ice & $\mathrm{R}$ & $\mathrm{R}[57]$ & $\mathrm{R}$ & $\mathrm{R}$ & $\mathrm{R}[57,58]$ & $\mathrm{R}[57-61]$ & $\mathrm{R}[57,58]$ \\
\hline Compression & $\mathrm{R}$ & $\mathrm{R}$ & $\mathrm{R}$ & $\mathrm{R}$ & $R[62-64]$ & $\mathrm{R}[65]$ & \\
\hline Elevation & $\mathrm{R}$ & $\mathrm{R}$ & $\mathrm{R}$ & $\mathrm{R}$ & R & R & \\
\hline Progressive strengthening exercises & $\mathrm{R}$ & $\mathrm{R}$ & & $\mathrm{R}$ & $\mathrm{R}[66-70]$ & $\begin{array}{l}R[45,49, \\
66,71]\end{array}$ & $\begin{array}{l}\text { R [66-68, } \\
72,73]\end{array}$ \\
\hline Balance exercises & $\mathrm{R}$ & $\mathrm{R}$ & & $\mathrm{R}$ & $R[66-69]$ & R [74-76] & $R[74-77]$ \\
\hline NSAIDs/paracetamol & $\begin{array}{l}\text { R\# [78- } \\
83]\end{array}$ & & $\mathrm{R}$ & $\mathrm{R}$ & & $\begin{array}{l}R[69,84, \\
85]\end{array}$ & \\
\hline Refer on to another discipline & & & $\mathrm{R}$ & R & $\mathrm{R}$ & & \\
\hline Advice DVT risk with immobilisation & $\mathrm{R}$ & & & & $\mathrm{R}$ & & \\
\hline Foot circle exercises & $\mathrm{R}$ & & & $\mathrm{R}$ & & & \\
\hline Alphabet exercises & & & & $\mathrm{R}$ & & & \\
\hline Lymphatic drainage/soft tissue mobilisations & & & & & & & $\mathrm{R}[86]$ \\
\hline Graded joint mobilisations or mobilisation with movement & & $\mathrm{R}[73]$ & & & $\begin{array}{l}X[69,73, \\
87]\end{array}$ & $\mathrm{R}[88,89]$ & $\begin{array}{l}R[44,73, \\
90]\end{array}$ \\
\hline Pulsating short wave diathermy & & $\begin{array}{l}X[91 \\
92]\end{array}$ & & & $X[91,92]$ & & $\mathrm{R}[92]$ \\
\hline Electrotherapy & & $x$ & & & $X[93-97]$ & $\mathrm{R}[98,99]$ & $\mathrm{R}[97,100]$ \\
\hline Low-level laser & & $x$ & & & $X[101]$ & & $\mathrm{R}[101,102]$ \\
\hline Heat & $x$ & & & $x$ & & $X[103]$ & \\
\hline Ultrasound & & $X[104]$ & & & $X[105]$ & $X[104]$ & $X[104,105]$ \\
\hline
\end{tabular}

Key: $\mathrm{R}=$ CPG recommends treatment, $\mathrm{X}=\mathrm{CPG}$ does not recommend treatment, $\#=$ analgesic dose. Blank $=$ this acute treatment choice was not included in CPG.

The second lowest domain score was domain 6, editorial independence. Three scored zero for this domain $[37,41,42]$. However, the more recent Dutch CPG [40] scored $97 \%$ for editorial independence. This CPG had information under the following headings: Contributors, Funding, Competing Interests, Provenance and Peer
Review and Author Affiliations. In this domain of editorial independence, the CPGs are assessed against the following statements:

The views of the funding body have not influenced the content of the CPG.

Table 4 Studies common in three or more clinical practice guidelines

\begin{tabular}{|c|c|c|c|c|c|c|c|c|}
\hline Studies & Type & 1 [36] (2006) & 2 [37] (2006) & 3 [38] (2009) & 4 [39] (2011) & $5[40](2012)$ & 6 [41] (2013) & 7 [42] (2013) \\
\hline Pasila (1978) [92] & RCT & & $\checkmark$ & & & $\checkmark$ & & $\checkmark$ \\
\hline Van der Windt (2002) [104] & SR & & $\checkmark$ & & & & $\checkmark$ & $\checkmark$ \\
\hline Kerkhoff (2002) [45] & SR & $\checkmark$ & $\checkmark$ & & & $\checkmark$ & $\checkmark$ & \\
\hline $\begin{array}{l}\text { Bleakley } \\
\text { (2004) [57] }\end{array}$ & SR & & $\checkmark$ & & & $\checkmark$ & $\checkmark$ & $\checkmark$ \\
\hline Bleakley (2006) [58] & RCT & & & & & $\checkmark$ & $\checkmark$ & $\checkmark$ \\
\hline Van der Wees (2006) [73] & SR & & $\checkmark$ & & & $\checkmark$ & & $\checkmark$ \\
\hline Kerkhoff (2007) [48] & SR & & & & & $\checkmark$ & $\checkmark$ & $\checkmark$ \\
\hline Lamb (2009) [47] & RCT & & & & & $\checkmark$ & $\checkmark$ & $\checkmark$ \\
\hline Bleakley (2010) [66] & $\mathrm{RCT}$ & & & & & $\checkmark$ & $\checkmark$ & $\checkmark$ \\
\hline
\end{tabular}

KEY: $\checkmark$ cited by this CPG, SR = Systematic Review, RCT = Randomised Clinical Trial 
Competing interests of members of the CPG development group have been recorded and addressed.

The third lowest domain score was for domain 3, rigour of development. Five of the CPGs [36-39, 41] scored below $31 \%$ for this domain. Our findings of the lowest scores in these three domains (rigour of development, applicability and editorial independence) are consistent with the findings of a systematic review of CPG appraisal studies [112]. That review showed that despite some increase in quality of CPGs over time, the quality of scores as measured with the AGREE tool has remained moderate to low over the last two decades. They saw significantly lower scores for the same three domains (rigour of development, applicability, and editorial independence) as we did, in CPGs published in 2003 or later.

This systematic review found poor consistency in the reporting of the levels of evidence and strength of acute recommendations. Two CPGs [38, 39] failed to describe the method of assessing the LOE and SOR and the remaining CPGs described differing methods. It is difficult for clinicians and researchers to have confidence in using recommendations if the method of assessment of evidence is not specified or is inconsistent. Current practice shows that CPG developers should use the Grading of Recommendations Assessment, Development and Evaluation (GRADE) tool for assessment of evidence. GRADE is an internationally recognised approach to rate the quality of evidence and the strength of recommendations and is the standard in CPG development [113]. The GRADE handbook states that the strength of recommendation for or against a specific treatment option should be expressed using two categories (weak and strong) [114].

The first CPG assessed in this study was published in 2006, the last in 2013. Factors that might necessitate CPGs to be updated have been discussed in the literature [115, 116]. These include changes in the evidence on the existing benefits and harms of treatments, outcomes considered important, available treatments, evidence that current practice is optimal, values placed on outcomes and resources available for health care. The most frequently recommended time between updates is $2-3$ years and the longest is five years. These time periods were found in a systematic review on the guidance for updating CPGs [117]. This indicates that the CPGs published before 2012 are outdated. So four of the CPGs in this study were out of date.

The secondary aim of this study was to determine if CPGs use the same studies to support their recommendations in the acute phase of a LALS. In this systematic review, there is a trend for CPG developers in different disciplines/fields to use the same studies to support their recommendations. However, this secondary objective has not been adequately achieved, in part based on a lack of an appropriate assessment tool. A previous systematic review of CPGs for the physical treatment of osteoarthritis categorised recommendations by grouped treatments with their associated $\mathrm{LOE}$ and SOR and then converted these into a scale from -4 to +4 [31]. This approach could not be taken in our analysis as the LALS CPGs were smaller in number and two CPGs failed to define LOE and SOR. In addition, many of the acute interventions were recommended on a consensus basis and therefore lacked high quality evidence. In another recent study aimed at critically appraising CPGs for foot and ankle treatments in rheumatoid arthritis, the researchers adopted a descriptive synthesis similar to our method described [118]. All three methods have their limitations and further research is needed to find a more valid and reliable way of assessing the quality of the CPG recommendations.

Inconsistency across CPGs suggests that the most contemporary high-level evidence is not being used by all CPG developers, however this criticism may be tempered by consideration of the differing ages of the CPGs. CPGs can recommend that a treatment be not recommended. For example, in a recent systematic review evaluating treatment strategies for acute LALS the authors found there was insufficient evidence to support the use of ultrasound as an treatment for LALS [119]. This recommendation of not using ultrasound for LALS has appeared in four CPGs [37, 40, 41].

When comparing the recommendations for treatments between American and Dutch guidelines there seems to be disparity. Graded joint mobilisations or mobilisation with movement, pulsating shortwave diathermy, electrotherapy, and low-level laser are not recommended by the Dutch CPGs. However, they are recommended by the American physical therapy CPG, despite some common studies used in development of both CPGs (see Table 3). The interpretation of the evidence between the two CPG development groups is clearly not consistent. Further research and robust studies into the conflicting recommendations are needed.

Only one CPG included a warning about using ice when sleeping with the term "do not" in bold. [36] The specific term "ice burn" was not used. The physical therapy curriculum in Australia advises such a warning [120], specifically, "If you feel any extreme discomfort or pain you must immediately tell .... [your physical therapist]: otherwise, you may be in danger of an ice burn." As circulation and nerve function may be compromised, caution is also advised when adding compression to cryotherapy [121]. Three CPGs advised against using heat if swelling was present in the acute LALS [38, 39, 41]. This is consistent with other research. Houghton et al. [121] advises that heat is not recommended for tissues inflamed as result of acute injury or exacerbation of 
chronic inflammatory condition or areas of severe swelling.

Two CPGs [36, 39] written for nurses have recommend, as a component of acute treatment early range-of-motion exercises including foot circles both clockwise and anticlockwise within 24-48 h of injury or to instruct the client to draw letters of the alphabet with their big toe held in the air. The same two CPGs advised warning for deep venous thrombosis (DVT) risk related to immobilisation for acute LALS [36, 39]. These CPGs may reflect the importance of preventing serious complications (DVT) in the nursing curriculum. However, there seems to be an inadequate understanding of the importance of not overstretching healing ligaments or delaying healing in a severe acute LALS. Further research into the nursing curriculum is recommended to clarify these concepts.

This systematic review found consistency in the use of progressive weightbearing with support in the acute phase for LALS except in two of the CPGs [36, 39]. In the American physical therapist CPG [42] the authors discuss that immobilisation and suturing is associated with improved mechanical stability on stress radiography. In addition, the authors discuss a cadaver study [122] that determined the optimal position for immobilization of severe LALS is a range of dorsiflexion angles between 5 and 15 degrees which reduced anterior talocrural subluxation. This reinforces to the authors that, in severe LALS, mobilisation with alphabet and foot circle exercises should be avoided early in treatment.

\section{Conclusions}

This study highlights areas of deficiency and where improvements are needed in the formulation of future LALS CPGs. The weakest areas were in rigour of development, applicability, and editorial independence. The methodology for assessing recommendations is not consistent between CPG developers. It is a critical question for clinicians whether CPGs are based on high quality evidence. It is of the opinion of the authors of this study that CPG development groups should utilise a validated methodolgy such as GRADE. This study may also inform methodology of critical appraisal of descriptive synthesis of the recommendations of CPGs for other injuries and conditions.

\section{Limitations}

The search procedure included databases, wide search terms and hand searching. Also, the search excluded CPGs not in English, a language filter was applied (see Additional file 1 Search Strategy and List of Articles). Future CPG LALS systematic reviews with international researchers may find CPGs in other languages. The AGREE II tool has limitations in that an absolute rate of agreement between the three reviewers cannot be calculated.

\section{Additional file}

Additional file 1: Search Strategy and List of Articles. (XLSX 23 kb)

\section{Abbreviations}

AGREE: Appraisal of Guidelines for REsearch and Evaluation; CAl: Chronic ankle instability; CPGs: Clinical practice guidelines; DVT: Deep venous thrombus; EBP: Evidence-based practice; GRADE: Grading of recommendations assessment, development, and evaluation; LALS: Lateral ankle ligament sprains; LOE: Level of Evidence; NSAIDs: Non-steroidal antiinflammatory drugs; PTOA: Post traumatic ankle osteoarthritis; RCTs: Randomised controlled trials; SOR: Strength of Recommendation

\section{Authors' contributions}

TG was the principal investigator and participated in all aspects of the study, including planning, contributed to the design of the study, study inclusion, the literature search, data screening and extraction, conducted all statistical analyses, and managed all aspects of manuscript preparation and submission. KF contributed to the design of the study, data screening and extraction, and contributed to writing and editing of the manuscript. GW contributed to the design of the study, data screening and extraction, and contributed to writing and editing of the manuscript. DM contributed to the design of the study, data screening and extraction, and contributed to writing and editing of the manuscript. All authors have read and approved the final manuscript.

\section{Funding}

Not Applicable

\section{Availability of data and materials}

All data generated or analysed during this study are included in this published article and its supplementary information files.

Ethics approval and consent to participate

Not Applicable

Consent for publication

Not Applicable

\section{Competing interests}

The authors declare that they have no competing interests.

\section{Author details}

${ }^{1}$ ANU Medical School, College of Health and Medicine, Australian National University, ACT, Acton, Australia. ${ }^{2}$ Discipline of Physiotherapy, University of Canberra, ACT, Bruce 2617, Australia. ${ }^{3}$ Elite Rehab and Sports Physiotherapy, Deakin, Canberra, Australia.

Received: 22 May 2018 Accepted: 2 August 2019

Published online: 31 August 2019

\section{References}

1. Fong DT-P, Hong Y, Chan L-K, Yung PS-H, Chan K-M. A systematic review on ankle injury and ankle sprain in sports. Sports Med. 2007:37:73-94.

2. Doherty C, Delahunt E, Caulfield B, Hertel J, Ryan J, Bleakley C. The incidence and prevalence of ankle sprain injury: a systematic review and meta-analysis of prospective epidemiological studies. Sports Med. 2014;44:123-40.

3. Lin C-WC, Uegaki K, Coupé VMH, Kerkhoffs GM, van Tulder MW. Economic evaluations of diagnostic tests, treatment and prevention for lateral ankle sprains: a systematic review. Br J Sports Med. 2013;47:1144-9.

4. Delahunt E, Coughlan GF, Caulfield B, Nightingale EJ, Lin C-WC, Hiller CE. Inclusion criteria when investigating insufficiencies in chronic ankle instability. Med Sci Sports Exerc. 2010;42:2106-21.

5. Gribble PA, Bleakley CM, Caulfield BM, Docherty CL, Fourchet F, Fong DT-P, Hertel J, Hiller CE, Kaminski TW, McKeon PO: 2016 Consensus statement of the international ankle consortium: prevalence, impact and long-term consequences of lateral ankle sprains. British Journal of sports medicine 2016:bjsports-2016-096188

6. Gribble PA, Bleakley CM, Caulfield BM, Docherty CL, Fourchet F, Fong DT-P, Hertel J, Hiller CE, Kaminski TW, McKeon PO: Evidence review for the 2016 
International Ankle Consortium consensus statement on the prevalence, impact and long-term consequences of lateral ankle sprains. British Journal of Sports Medicine 2016:bjsports-2016-096189.

7. Gribble PA, Delahunt E, Bleakley CM, Caulfield B, Docherty CL, Fong DT-P, Fourchet F, Hertel J, Hiller CE, Kaminski TW, et al. Selection Criteria for Patients With Chronic Ankle Instability in Controlled Research: A Position Statement of the International Ankle Consortium. J Athl Train. 2014;49:121-7.

8. Liow R, McNicholas M, Keating J, Nutton R. Ligament repair and reconstruction in traumatic dislocation of the knee. Bone and Joint Journal. 2003;85:845-51.

9. Petersen W, Rembitzki IV, Koppenburg AG, Ellermann A, Liebau C, Brüggemann GP, Best R. Treatment of acute ankle ligament injuries: a systematic review. Arch Orthop Trauma Surg. 2013;133:1129-41.

10. McKay GD, Goldie PA, Payne WR, Oakes BW. Ankle injuries in basketball: injury rate and risk factors. Br J Sports Med. 2001;35:103-8.

11. Woods C, Hawkins R, Hulse M, Hodson A. The football association medical research Programme: an audit of injuries in professional football: an analysis of ankle sprains. Br J Sports Med. 2003;37:233-8.

12. Cameron $\mathrm{KL}$, Owens $\mathrm{BD}$, DeBerardino TM. Incidence of ankle sprains among active-duty members of the United States armed services from 1998 through 2006. J Athl Train. 2010;45:29-38.

13. Bronner S, Brownstein B. Profile of dance injuries in a Broadway show: a discussion of issues in dance medicine epidemiology. J Orthop Sports Phys Ther. 1997;26:87-94

14. Byhring $S, B \varnothing$ K. Musculoskeletal injuries in the Norwegian National Ballet: a prospective cohort study. Scand J Med Sci Sports. 2002;12:365-70.

15. Anandacoomarasamy $A$, Barnsley L. Long term outcomes of inversion ankle injuries. Br J Sports Med. 2005;39:e14.

16. Hertel J. Functional instability following lateral ankle sprain. Sports Med. 2000:29:361-71.

17. Hiller CE, Nightingale EJ, Lin C-WC, Coughlan GF, Caulfield B, Delahunt E: Characteristics of people with recurrent ankle sprains: a systematic review with meta-analysis. British journal of sports medicine 2011:bjsports77404.

18. Valderrabano V, Hintermann B, Horisberger M, Fung TS. Ligamentous posttraumatic ankle osteoarthritis. Am J Sports Med. 2006;34:612-20.

19. Menz HB, Morris ME, Lord SR. Foot and ankle risk factors for falls in older people: a prospective study. The Journals of Gerontology: Series A. 2006;61:866-70.

20. Bridgman SA, Clement D, Downing A, Walley G, Phair I, Maffulli N. Population based epidemiology of ankle sprains attending accident and emergency units in the west midlands of England, and a survey of UK practice for severe ankle sprains. Emerg Med J. 2003;20:508-10.

21. Waterman BR, Owens BD, Davey S, Zacchilli MA, Belmont PJ Jr. The epidemiology of ankle sprains in the United States. J Bone Joint Surg Am. 2010;92:2279-84.

22. Van Rijn RM, Van Os AG, Bernsen RM, Luijsterburg PA, Koes BW, BiermaZeinstra SM. What is the clinical course of acute ankle sprains? A systematic literature review. The American journal of medicine. 2008;121:324-331. e327.

23. Lang ES, Wyer PC, Haynes RB. Knowledge translation: closing the evidenceto-practice gap. Ann Emerg Med. 2007;49:355-63.

24. Davis D, Davis ME, Jadad A, Perrier L, Rath D, Ryan D, Sibbald G, Straus S, Rappolt S, Wowk M. The case for knowledge translation: shortening the journey from evidence to effect. Bmj. 2003;327:33-5.

25. Brouwers MC, Kho ME, Browman GP, Burgers JS, Cluzeau F, Feder G, Fervers B, Graham ID, Grimshaw J, Hanna SE. AGREE II: advancing guideline development, reporting and evaluation in health care. Can Med Assoc J. 2010;182:E839-42

26. Byrt T, Bishop J, Carlin JB. Bias, prevalence and kappa. J Clin Epidemiol. 1993;46:423-9.

27. Brouwers MC, Kho ME, Browman GP, Burgers JS, Cluzeau F, Feder G, Fervers B, Graham ID, Hanna SE, Makarski J. Development of the AGREE II, part 2: assessment of validity of items and tools to support application. Can Med Assoc J. 2010;182:E472-8.

28. Brouwers MC, Kho ME, Browman GP, Burgers JS, Cluzeau F, Feder G, Fervers B, Graham ID, Hanna SE, Makarski J. Development of the AGREE II, part 1: performance, usefulness and areas for improvement. Can Med Assoc J. 2010;182:1045-52.

29. Vlayen J, Aertgeerts B, Hannes K, Sermeus W, Ramaekers D. A systematic review of appraisal tools for clinical practice guidelines: multiple similarities and one common deficit. Int J Qual Health Care. 2005;17:235-42.

30. Zeng X, Zhang Y, Kwong JS, Zhang C, Li S, Sun F, Niu Y, Du L. The methodological quality assessment tools for preclinical and clinical studies, systematic review and meta-analysis, and clinical practice guideline: a systematic review. J Evid Based Med. 2015:8:2-10.
31. Larmer PJ, Reay ND, Aubert ER, Kersten P. Systematic review of guidelines for the physical management of osteoarthritis. Arch Phys Med Rehabil. 2014 95:375-89.

32. Dagenais S, Tricco AC, Haldeman S. Synthesis of recommendations for the assessment and management of low back pain from recent clinical practice guidelines. Spine J. 2010;10:514-29.

33. Reuters T. EndNote X7. Philadelphia, PA, USA: Thomson Reuters; 2013.

34. Richie DH, Izadi FE: Return to Play After an Ankle Sprain Guidelines for the Podiatric Physician. Clinics in Podiatric Medicine and Surgery 2015, 32:195-+

35. Lin CF, Gross MT, Weinhold P. Ankle syndesmosis injuries: anatomy, biomechanics, mechanism of injury, and clinical guidelines for diagnosis and intervention. J Orthop Sports Phys Ther. 2006;36:372-84.

36. Fongemie A, Ddudera A, Strandemo G. Health care guideline: ankle sprain. Institute for Clinical Systems Improvement www ICSI org Zugriff am. 2006;23:2011.

37. Wees $P$, Lenssen A, Feijts $Y$, Bloo H, van Morsel S, Ouderland R, Opraus K, Rondhuis G, Simons A, Swinkels R. KNGF guideline for physical therapy in patients with acute ankle sprain-practice guidelines. Suppl Dutch J Phys Ther. 2006;116:1-30.

38. Occupational Health Nurse Practitioner (OHNP) Clinical Practice Guideline (CPG), Ankle/Foot Injury [http://www.nursing.health.wa.gov.au/docs/career/ $\mathrm{np} /$ carepoint/cpg_ankle_foot_injury.pdf] accessed 26 October 2017.

39. Adult Care, Chapter 7, Musculoskeletal System [https://www.canada.ca/en/ health-canada/services/first-nations-inuit-health/health-care-services/nursing/ clinical-practice-guidelines-nurses-primary-care/adult-care/chapter-7musculoskeletal-system.html\#a7] accessed 26 October 2017.

40. Kerkhoffs GM, van den Bekerom M, Elders LAM, van Beek PA, Hullegie WAM, Bloemers GMFM, de Heus EM, Loogman MCM. Rosenbrand KCJGM, Kuipers T, et al: diagnosis, treatment and prevention of ankle sprains: an evidencebased clinical guideline. Br J Sports Med. 2012;46:854-60.

41. Kaminski TW, Hertel J, Amendola N, Docherty CL, Dolan MG, Hopkins JT, Nussbaum E, Poppy W, Richie D. National Athletic Trainers' association position statement: conservative management and prevention of ankle sprains in athletes. J Athl Train. 2013;48:528-45.

42. Martin RL, Davenport TE, Paulseth S, Wukich DK, Godges JJ: Ankle Stability and Movement Coordination Impairments: Ankle Ligament Sprains. Journal of Orthopaedic \& Sports Physical Therapy 2013, 43:A1-A40.

43. Ardèvol J, Bolíbar I, Belda V, Argilaga S. Treatment of complete rupture of the lateral ligaments of the ankle: a randomized clinical trial comparing cast immobilization with functional treatment. Knee Surg Sports Traumatol Arthrosc. 2002;10:371-7.

44. Green T, Refshauge K, Crosbie J, Adams R. A randomized controlled trial of a passive accessory joint mobilization on acute ankle inversion sprains. Phys Ther. 2001;81:984-94.

45. Kerkhoffs G, Rowe BH, Assendelft W, Kelly K, Struijs P, Van Dijk C. Immobilisation and functional treatment for acute lateral ankle ligament injuries in adults. Cochrane Database Syst Rev. 2002;3.

46. Kerkhoffs GM, Struijs PA, Marti RK, Assendelft WJ, Blankevoort L, Van Dijk C. Different functional treatment strategies for acute lateral ankle ligament injuries in adults. Cochrane Libr. 2002.

47. Lamb SE, Marsh JL, Hutton JL, Nakash R, Cooke MW. Collaborative ankle support T: mechanical supports for acute, severe ankle sprain: a pragmatic, multicentre, randomised controlled trial. Lancet. 2009;373:575-81.

48. Kerkhoffs GM, Handoll HH, de Bie R, Rowe BH, Struijs PA. Surgical versus conservative treatment for acute injuries of the lateral ligament complex of the ankle in adults. The Cochrane Library. 2007.

49. Beynnon BD, Renström PA, Haugh L, Uh BS, Barker H. A prospective randomized clinical investigation of the treatment of first-time ankle sprains. Am J Sports Med. 2006;34:1401-12.

50. Kerkhoffs GM, Rowe BH, Assendelft WJ, Kelly KD, Struijs PA, van Dijk CN. Immobilisation for acute ankle sprain. Arch Orthop Trauma Surg. 2001;121:462-71.

51. Lamb S, Nakash RA, Withers EJ, Clark M, Marsh J, Wilson S, Hutton J, Szczepura A, Dale J, Cooke M. Clinical and cost effectiveness of mechanical support for severe ankle sprains: design of a randomised controlled trial in the emergency department [ISRCTN 37807450]. BMC Musculoskelet Disord. 2005;6:1.

52. Dettori J, Basmania C. Early ankle mobilization, part II: a one-year follow-up of acute, lateral ankle sprains (a randomized clinical trial). Mil Med. 1994;159:20-4.

53. Cooke MW, Lamb SE, Marsh J, Dale J. A survey of current consultant practice of treatment of severe ankle sprains in emergency departments in the United Kingdom. Emerg Med J. 2003;20.

54. Cooke M, Marsh J, Clark M, Nakash RA, Jarvis RM, Hutton JS, Szczepura A, Wilson S, Lamb SE. Treatment of severe ankle sprain: a pragmatic 
randomised controlled trial comparing the clinical effectiveness and costeffectiveness of three types of mechanical ankle support with tubular bandage: the CAST trial. Health Technol Assess. 2009;13:1-121.

55. Kemler E, van de Port I, Backx F, van Dijk CN. A systematic review on the treatment of acute ankle sprain. Sports Med. 2011;41:185-97.

56. Freeman M. Treatment of ruptures of the lateral ligament of the ankle. Bone Joint J. 1965;47:661-8.

57. Bleakley C, McDonough S, MacAuley D. The use of ice in the treatment of acute soft-tissue injury. Am J Sports Med. 2004;32:251-61.

58. Bleakley CM, McDonough SM, MacAuley DC. Cryotherapy for acute ankle sprains: a randomised controlled study of two different icing protocols. $\mathrm{Br} J$ Sports Med. 2006;40:700-5.

59. Hubbard TJ, Aronson SL, Denegar CR. Does cryotherapy hasten return to participation? A systematic review. J Athl Train. 2004;39:88-94.

60. Knight KL. Cryotherapy in sport injury management: Human Life Press; 1995.

61. Pincivero D, Gieck JH, Saliba EN. Rehabilitation of a lateral ankle sprain with cryokinetics and functional progressive exercise. J Sport Rehabil. 1993;2:200-7.

62. Airaksinen $\mathrm{O}$, Kolari PJ, Miettinen $\mathrm{H}$. Elastic bandages and intermittent pneumatic compression for treatment of acute ankle sprains. Arch Phys Med Rehabil. 1990;71:380-3.

63. Rucinski TJ, Hooker DN, Prentice WE Jr, Shields EW Jr, Coté-Murray DJ. The effects of intermittent compression on edema in postacute ankle sprains. J Orthop Sports Phys Ther. 1991;14:65-9.

64. Tsang KK, Hertel J, Denegar CR. Volume decreases after elevation and intermittent compression of postacute ankle sprains are negated by gravitydependent positioning. J Athl Train. 2003;38:320.

65. Wilkerson GB, Horn-Kingery HM. Treatment of the inversion ankle sprain: comparison of different modes of compression and cryotherapy. J Orthop Sports Phys Ther. 1993:17:240-6.

66. Bleakley CM, O'Connor SR, Tully MA, Rocke LG, MacAuley DC, Bradbury I, Keegan S, McDonough SM. Effect of accelerated rehabilitation on function after ankle sprain: randomised controlled trial. BMJ. 2010;340.

67. Van Rijn RM, Van Os AG, Kleinrensink G-J, Bernsen RMD, Verhaar JAN, Koes BW, Bierma-Zeinstra SMA. Supervised exercises for adults with acute lateral ankle sprain: a randomised controlled trial. Br J Gen Pract. 2007;57:793-800

68. Van Rijn R. Heest JACV, Van der Wees P, Koes BW, Bierma-Zeinstra SMA: some benefit from physiotherapy intervention in the subgroup of patients with severe ankle sprain as determined by the ankle function score: a randomised trial. Aust J Physiother. 2009;55:107-13.

69. Bleakley CM, McDonough SM, MacAuley DC. Some conservative strategies are effective when added to controlled mobilisation with external support after acute ankle sprain: a systematic review. Aust J Physiother. 2008;54:7-20.

70. Van Os AG, Bierma-Zeinstra SM, Verhagen AP, de Bie RA, Luijsterburg PA, Koes BW. Comparison of conventional treatment and supervised rehabilitation for treatment of acute lateral ankle sprains: a systematic review of the literature. J Orthop Sports Phys Ther. 2005:35:95-105.

71. Docherty $\mathrm{CL}$, Moore $\mathrm{JH}$, Arnold BL. Effects of strength training on strength development and joint position sense in functionally unstable ankles. J Athl Train. 1998:33:310.

72. Hale SA, Hertel J, Olmsted-Kramer LC. The effect of a 4-week comprehensive rehabilitation program on postural control and lower extremity function in individuals with chronic ankle instability. J Orthop Sports Phys Ther. 2007;37:303-11.

73. Van der Wees PJ, Lenssen AF, Hendriks EJ, Stomp DJ, Dekker J, de Bie RA. Effectiveness of exercise therapy and manual mobilisation in acute ankle sprain and functional instability: a systematic review. Aust J Physiother. 2006;52:27-37.

74. Holme E, Magnusson S, Becher K, Bieler T, Aagaard P, Kjaer M. The effect of supervised rehabilitation on strength, postural sway, position sense and re-injury risk after acute ankle ligament sprain. Scand J Med Sci Sports. 1999;9:104-9.

75. McKeon PO, Hertel J. Systematic review of postural control and lateral ankle instability, part II: is balance training clinically effective? J Athl Train. 2008:43:305-15.

76. Wester JU, Jespersen SM, Nielsen KD, Neumann L. Wobble board training after partial sprains of the lateral ligaments of the ankle: a prospective randomized study. J Orthop Sports Phys Ther. 1996;23:332-6.

77. Bassett SF, Prapavessis H. Home-based physical therapy intervention with adherence-enhancing strategies versus clinic-based management for patients with ankle sprains. Phys Ther. 2007;87:1132-43.

78. Bradley JD, Brandt KD, Katz BP, Kalasinski LA, Ryan SI. Comparison of an antiinflammatory dose of ibuprofen, an analgesic dose of ibuprofen, and acetaminophen in the treatment of patients with osteoarthritis of the knee. N Engl J Med. 1991;325:87-91.
79. Dupont M, Béliveau P, Theriault G. The efficacy of antiinflammatory medication in the treatment of the acutely sprained ankle. Am J Sports Med. 1987;15:41-5.

80. Fredberg U, Hansen PA, Skinhøj A. Ibuprofen in the treatment of acute ankle joint injuries: a double-blind study. Am J Sports Med. 1989;17:564-6.

81. James Williams H, Ward JR, Egger MJ, Neuner R, Brooks RH, Clegg DO, Field EH, Skosey JL, Alarcón GS, Willkens RF, et al. Comparison of naproxen and acetaminophen in a two-year study of treatment of osteoarthritis of the knee. Arthritis and Rheumatism. 1993;36:1196-206.

82. Cooper $\mathrm{S}$, Kupperman A. The analgesic efficacy of flurbiprofen compared to acetaminophen with codeine. J Clin Dent. 1991;2:70-4.

83. Forbes JA, Butterworth GA, Burchfield WH, Beaver WT. Evaluation of ketorolac, aspirin, and an acetaminophen-codeine combination in postoperative Oral surgery pain. Pharmacotherapy: The Journal of Human Pharmacology and Drug Therapy. 1990;10.

84. Mazières B, Rouanet S, Velicy J, Scarsi C, Reiner V. Topical Ketoprofen patch (100 mg) for the treatment of ankle sprain. Am J Sports Med. 2005;33:515-23.

85. Slatyer MA, Hensley MJ, Lopert R. A randomized controlled trial of piroxicam in the management of acute ankle sprain in Australian regular Army recruits: the Kapooka ankle sprain study. Am J Sports Med. 1997;25:544-53.

86. Eisenhart AW, Gaeta TJ, Yens DP. Osteopathic manipulative treatment in the emergency department for patients with acute ankle injuries. J Am Osteopath Assoc. 2003;103:417-21.

87. Brantingham JW, Globe G, Pollard H, Hicks M, Korporaal C, Hoskins W. Manipulative therapy for lower extremity conditions: expansion of literature review. J Manip Physiol Ther. 2009;32:53-71.

88. Denegar CR, Hertel J, Fonseca J. The effect of lateral ankle sprain on dorsiflexion range of motion, posterior talar glide, and joint laxity. J Orthop Sports Phys Ther. 2002;32:166-73.

89. Vicenzino B, Branjerdporn M, Teys $\mathrm{P}$, Jordan K. Initial changes in posterior talar glide and dorsiflexion of the ankle after mobilization with movement in individuals with recurrent ankle sprain. J Orthop Sports Phys Ther. 2006; 36:464-71.

90. Collins $N$, Teys P, Vicenzino B. The initial effects of a Mulligan's mobilization with movement technique on dorsiflexion and pain in subacute ankle sprains. Man Ther. 2004;9:77-82.

91. Barker A, Barlow P, Porter J, Smith M, Clifton S, Andrews L, O'Dowd W. A double-blind clinical trial of low power pulsed shortwave therapy in the treatment of a soft tissue injury. Physiotherapy. 1985;71:500-4.

92. Pasila M, Visuri T, Sundholm A. Pulsating shortwave diathermy: value in treatment of recent ankle and foot sprains. Arch Phys Med Rehabil. 1978;59:383-6.

93. Health Council of the Netherlands: Effectiveness of physical therapy; electrotherapy, lasertherapy, ultrasound therapy. The Hague: Health Council of the Netherlands. 1999, publication no. 1999/20.

94. Mendel FC, Dolan MG, Fish DR, Marzo J, Wilding GE. Effect of high-voltage pulsed current on recovery after grades I and II lateral ankle sprains. J Sport Rehabil. 2010;19:399-410.

95. Michlovitz S, Smith W, Watkins M. Ice and high voltage pulsed stimulation in treatment of acute lateral ankle sprains. J Orthop Sports Phys Ther. 1988:9:301-4.

96. Pennington G, Danley D, Sumko M, Bucknell A, Nelson J. Pulsed, nonthermal, high-frequency electromagnetic energy (DIAPULSE) in the treatment of grade I and grade II ankle sprains. Mil Med. 1993;158:101-4.

97. Wilson D. Treatment of soft-tissue injuries by pulsed electrical energy. $\mathrm{Br}$ Med J. 1972;2:269-70.

98. Dolan MG, Mychaskiw AM, Mendel FC. Cool-water immersion and highvoltage electric stimulation curb edema formation in rats. J Athl Train. 2003; 38:225-30.

99. Snyder AR, Perotti AL, Lam KC, Bay RC. The influence of high-voltage electrical stimulation on edema formation after acute injury: a systematic review. J Sport Rehabil. 2010;19:436-51.

100. Man IO, Morrissey MC, Cywinski JK. Effect of neuromuscular electrical stimulation on ankle swelling in the early period after ankle sprain. Phys Ther. 2007:87:53-65.

101. de Bie RA, de Vet HCW, Lenssen TF, van den Wildenberg FAJM, Kootstra G, Knipschild PG. Low-level laser therapy in ankle sprains: a randomized clinical trial. Arch Phys Med Rehabil. 1998;79:1415-20.

102. Stergioulas A. Low-level laser treatment can reduce edema in second degree ankle sprains. J Clin Laser Med Surg. 2004:22:125-8.

103. Coté DJ, Prentice WE Jr, Hooker DN, Shields EW. Comparison of three treatment procedures for minimizing ankle sprain swelling. Phys Ther. 1988; 68:1072-6. 
104. Van der Windt D, Van der Heijden G, Van den Berg S, Ter Riet G, De Winter AF, Bouter LM, van den Bekerom MP. Therapeutic ultrasound for acute ankle sprains. Cochrane Database Syst Rev. 2002;1.

105. Van den Bekerom M, Van der Windt D, Riet G, Van der Heijden G, Bouter L. Therapeutic ultrasound for acute ankle sprains; 2012.

106. Braund R, Bannerman SL, Lim C, Moon J, Nicholls J, Straight P, Thompson M. Recommendations of community pharmacists for the treatment of sprains and strains. Int J Pharm Pract. 2006;14:271-6.

107. Handbook AM: AUSTRALIAN MEDICINES HANDBOOK 2017. AUSTRALIAN MEDICINES HAND; 2017.

108. Scott SD, Albrecht L, O'Leary K, Ball GD, Hartling L, Hofmeyer A, Jones CA, Klassen TP, Burns KK, Newton AS. Systematic review of knowledge translation strategies in the allied health professions. Implement Sci. 2012;7:70.

109. Leemriise CJ, Plas GM, Hofhuis H, van den Ende CHM. Compliance with the guidelines for acute ankle sprain for physiotherapists is moderate in the Netherlands: an observational study. Aust J Physiother. 2006;52:293-8.

110. Van Der Wees PJ, Hendriks EJ, Jansen MJ, Van Beers H, De Bie RA, Dekker J. Adherence to physiotherapy clinical guideline acute ankle injury and determinants of adherence: a cohort study. BMC Musculoskelet Disord. 2007;8.

111. Kooijman MK, Swinkels ICS, Veenhof C, Spreeuwenberg P, Leemrijse CJ. Physiotherapists' compliance with ankle injury guidelines is different for patients with acute injuries and patients with functional instability: an observational study. J Physiother. 2011;57:41-6.

112. Alonso-Coello P, Irfan A, Solà I, Gich I, Delgado-Noguera M, Rigau D, Tort S, Bonfill X, Burgers J, Schunemann $\mathrm{H}$. The quality of clinical practice guidelines over the last two decades: a systematic review of guideline appraisal studies. Qual Saf Health Care. 2010;19:e58.

113. Andrews JC, Schünemann HJ, Oxman AD, Pottie K, Meerpohl JJ, Coello PA, Rind D, Montori VM, Brito JP, Norris S, et al. GRADE guidelines: 15. Going from evidence to recommendation-determinants of a recommendation's direction and strength. J Clin Epidemiol. 2013;66:726-35.

114. Schünemann H, Brożek J, Guyatt G, Oxman a: GRADE handbook for grading quality of evidence and strength of recommendations. Updated. The GRADE Working Group, 2013. October 2013:2014.

115. Shekelle P, Eccles MP, Grimshaw JM, Woolf SH. When should clinical guidelines be updated? BMJ. 2001;323:155-7.

116. Shekelle P, Woolf S, Grimshaw JM, Schünemann HJ, Eccles MP. Developing clinical practice guidelines: reviewing, reporting, and publishing guidelines; updating guidelines; and the emerging issues of enhancing guideline implementability and accounting for comorbid conditions in guideline development. Implement Sci. 2012;7:62.

117. Vernooij RWM, Sanabria AJ, Solà I, Alonso-Coello P, Martínez García L. Guidance for updating clinical practice guidelines: a systematic review of methodological handbooks. Implementation Science : IS. 2014;9:3-3.

118. Hennessy K, Woodburn J, Steultjens M. Clinical practice guidelines for the foot and ankle in rheumatoid arthritis: a critical appraisal. J Foot Ankle Res. 2016;9.

119. Doherty C, Bleakley C, Delahunt E, Holden S. Treatment and prevention of acute and recurrent ankle sprain: an overview of systematic reviews with meta-analysis. Br J Sports Med. 2017;51:113-25.

120. Robertson VJCL, Laakso EL, Whelan KM, McKenna LJ. Guidelines for the clinical use of electrophysical agents. St Kilda Road Central, Vic: Australian Physiotherapy Association; 2001.

121. Houghton PNE, Hoens A. ELECTROPHYSICAL AGENTS - contraindications and precautions: an evidence-based approach to clinical decision making in physical therapy. Physiother Can. 2010;62:1-80.

122. Smith RW, Reischl S. The influence of dorsiflexion in the treatment of severe ankle sprains: an anatomical study. Foot Ankle Int. 1988;9:28-33.

\section{Publisher's Note}

Springer Nature remains neutral with regard to jurisdictional claims in published maps and institutional affiliations.

Ready to submit your research? Choose BMC and benefit from:

- fast, convenient online submission

- thorough peer review by experienced researchers in your field

- rapid publication on acceptance

- support for research data, including large and complex data types

- gold Open Access which fosters wider collaboration and increased citations

- maximum visibility for your research: over $100 \mathrm{M}$ website views per year

At $\mathrm{BMC}$, research is always in progress.

Learn more biomedcentral.com/submissions 